\title{
THE COMPARISON OF UREA WITH UREA + AMMONIA CLEARANCES IN ACIDOTIC DOGS
}

\author{
By ROBERT F. PITTS \\ (From the Department of Physiology, New York University, College of Medicine, \\ New York City)
}

(Received for publication June 4, 1936)

In 1921 Nash and Benedict (11) advanced the hypothesis that urinary ammonia is formed in the kidney from some precursor in the blood. This conclusion was based upon the observation that the concentration of ammonia was higher in the renal vein than in the renal artery, that the quantity of ammonia in arterial blood was too small to supply the ammonia found in the urine, and that the arterial ammonia concentration was unaffected by acidosis, alkalosis, and nephrectomy, which procedures modify the excretion of ammonia. This hypothesis has been supported by Loeb, Atchley and Benedict (8) and Rabinowitch (13). The nature of the precursor is, however, not established; Bliss (2) has suggested amide nitrogen of protein, Krebs (7) has suggested amino nitrogen, and Nash and Benedict (11), Keeton (6), Mann and Bollman (9) have suggested urea nitrogen. Steenbock, Nelson and Hart (18) and Keeton (6) have claimed that in acidosis a reciprocal relation exists between the excretion of urea and ammonia nitrogen, such that the increased excretion of the latter is compensated by a decreased excretion of the former, but McCollum and Hoagland (10) and Adolph (1) have asserted that the total nitrogen excretion increases to an extent equivalent to the increased ammonia excretion.

Van Slyke, Page, Hiller and Kirk (21), accepting the hypothesis that ammonia is formed in the kidney from urea, have recommended that the sum of urea + ammonia nitrogen in the urine be used in calculating the equivalent of the urea clearance in acidosis. This urea + ammonia clearance, they believe, has the same functional significance in acidotic individuals as has the urea clearance under normal conditions. In support of their hypothesis they present comparisons of the urea clearance in normal men on a normal diet with urea + ammonia clearances on a low protein diet with induced acidosis.
It is known that in both dog and man (17) the urea clearance is considerably less than the rate of glomerular filtration, the deficit in the urea clearance being commonly attributed to the reabsorption of urea. It would be unjustified to link this deficit in the urea clearance with the process of ammonia formation, since it exists at all times, whether ammonia is being excreted or not. Nevertheless, any decomposition of filtered urea would reduce the urea clearance to a further extent, and thus supplement the normal deficit. (Such decomposition might occur either in the lumen of the renal tubules, or in the tubule cells after the reabsorption of a fraction of the filtered urea from the tubular urine). In fact, if the conclusions of Van Slyke et al. (21) are correct -i.e., if the urea + ammonia clearance in acidosis is of the same magnitude and has the same functional significance as has the urea clearance in the normal-it follows that ammonia excretion does in fact create a further deficit in the urea clearance, and that urinary ammonia is derived directly or indirectly from urea that has been initially present in the glomerular filtrate. And by the same reasoning, if the implied reciprocal relation between the clearances were an exact one, the formation of ammonia from any other nitrogenous precursor would be ruled out of consideration. Van Slyke, Page, Hiller and Kirk do not comment on these and other physiological implications necessarily issuing from their conclusions. The problem seemed, therefore, of sufficient interest to justify further examination.

There are certain features, moreover, in the observations of these investigators that render their interpretation uncertain. It is known that all renal clearances in both man and dogs are affected by the protein content of the diet $(3,5$, $12,14,15)$. It seemed not beyond possibility that on a protein-poor diet such as was used by Van Slyke and his coworkers in acidotics, all 
TABLE I

A comparison of the urea, the urea plus ammonia, and the creatinine clearances at low and high plasma urea concentrations in the acidotic dog

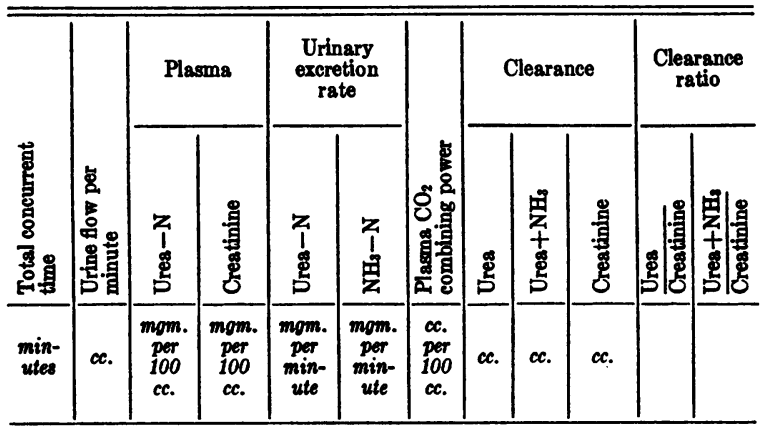

Experiment 13, Dog S. B.

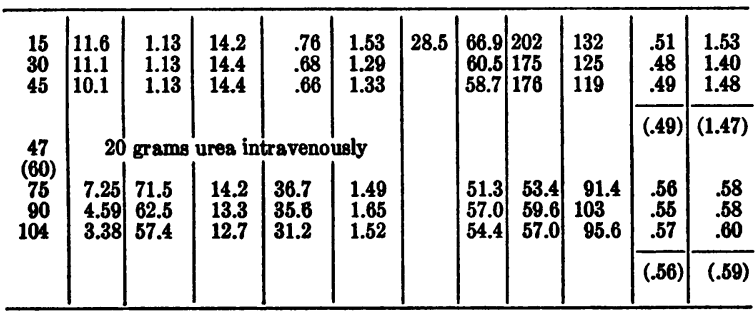

clearances might be reduced without any specific depression of the urea clearance. In one individual (Table II) they attempt to rule out this possibility by including the creatinine clearance as a standard of reference, but the data presented show such marked variations within themselves that they cannot confidently be interpreted.

We have therefore examined the excretion of urea and ammonia in the dog under more controlled and exacting conditions. Female dogs were used and fed a maintenance, low-protein diet, consisting of cracker meal with butter, yeast, cod liver oil and salt. To induce acidosis the dogs were given $5 \mathrm{cc}$. of concentrated hydrochloric acid well diluted with water each day for several days, and in later experiments they were given 2 liters of water the day before an experiment to induce diuresis and thus reduce the blood urea concentration. Urea was determined by the gasometric method of Van Slyke (19), using 2 cc. of plasma where the plasma urea was low. After the administration of sodium bicarbonate it was necessary to add excess acid to both plasma and urine to insure removal of preformed carbon dioxide in the determination of urea. Creatinine was determined on diluted urine and tungstic acid
TABLE II

A summary of comparisons of the urea, the urea plus ammonia, and the creatinine clearances at low and high plasma urea concentrations in acidotic dogs

\begin{tabular}{|c|c|c|c|c|c|c|c|c|c|c|c|}
\hline \multirow{2}{*}{ 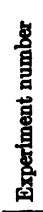 } & \multirow[b]{2}{*}{ 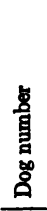 } & \multirow{2}{*}{ 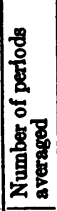 } & \multirow[b]{2}{*}{ 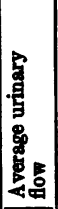 } & \multirow{2}{*}{ 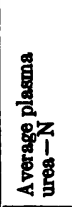 } & \multirow{2}{*}{ 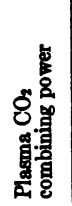 } & \multirow{2}{*}{ 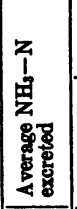 } & \multicolumn{3}{|c|}{ Clearance } & \multicolumn{2}{|c|}{$\begin{array}{c}\text { Clearance } \\
\text { ratios }\end{array}$} \\
\hline & & & & & & & 导 & 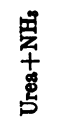 & $\begin{array}{l}\text { 员 } \\
\text { 意 } \\
\text { 品 }\end{array}$ & 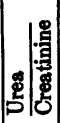 & 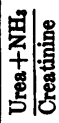 \\
\hline & & & $\propto$. & $\begin{array}{c}\text { mom. } \\
\text { per } \\
100 \mathrm{cc} .\end{array}$ & $\begin{array}{c}c c . \\
\text { per } \\
100 \mathrm{cc} .\end{array}$ & $\mid \begin{array}{c}\text { mom. } \\
\text { per } \\
\text { minute }\end{array}$ & $\boldsymbol{c c}$ & cc. & cc. & & \\
\hline 1 & 2 & $\begin{array}{l}3 \\
3\end{array}$ & $\begin{array}{l}5.2 \\
3.6\end{array}$ & $\begin{array}{c}1.84 \\
64.0\end{array}$ & & $\begin{array}{l}.79 \\
.91\end{array}$ & $\begin{array}{l}60.9 \\
44.2\end{array}$ & $\begin{array}{r}104.1 \\
45.6\end{array}$ & $\begin{array}{r}104.7 \\
79.3\end{array}$ & $\begin{array}{l}.58 \\
.56\end{array}$ & $\begin{array}{l}.99 \\
.57\end{array}$ \\
\hline 2 & 2 & $\begin{array}{l}\mathbf{3} \\
\mathbf{3}\end{array}$ & $\begin{array}{l}3.4 \\
4.6\end{array}$ & $\begin{array}{r}2.19 \\
74.8\end{array}$ & & $\begin{array}{l}.55 \\
.79\end{array}$ & $\begin{array}{l}51.2 \\
\mathbf{4 2 . 3}\end{array}$ & $\begin{array}{l}76.1 \\
43.3\end{array}$ & $\begin{array}{l}94.9 \\
78.4\end{array}$ & .54 & .80 \\
\hline 4 & 4 & $\begin{array}{l}3 \\
3\end{array}$ & $\begin{array}{l}6.4 \\
3.4\end{array}$ & $\begin{array}{c}1.98 \\
78.4\end{array}$ & 37 & $\begin{array}{r}.92 \\
1.07\end{array}$ & \begin{tabular}{|l|}
45.0 \\
3.6 .6
\end{tabular} & $\begin{array}{l}91.3 \\
38.0\end{array}$ & $\begin{array}{l}83.8 \\
63.5\end{array}$ & $\begin{array}{l}.54 \\
.58\end{array}$ & $\begin{array}{r}1.09 \\
.60\end{array}$ \\
\hline 5 & 4 & $\begin{array}{l}\mathbf{3} \\
\mathbf{3}\end{array}$ & $\begin{array}{l}6.4 \\
3.8\end{array}$ & $\begin{array}{c}2.50 \\
73.4\end{array}$ & 36 & $\begin{array}{l}.89 \\
.96\end{array}$ & \begin{tabular}{|l|}
47.0 \\
37.5
\end{tabular} & $\begin{array}{l}82.7 \\
38.8\end{array}$ & $\begin{array}{l}89.5 \\
68.4\end{array}$ & $\begin{array}{l}.53 \\
.55\end{array}$ & $\begin{array}{l}.92 \\
.57\end{array}$ \\
\hline 7 & 1 & $\begin{array}{l}\mathbf{3} \\
\mathbf{3}\end{array}$ & $\begin{array}{l}3.6 \\
4.9\end{array}$ & $\begin{array}{r}1.60 \\
111.0\end{array}$ & 41 & $\begin{array}{l}.49 \\
.61\end{array}$ & \begin{tabular}{|l|}
24.1 \\
24.2
\end{tabular} \mid & $\begin{array}{l}54.6 \\
24.8\end{array}$ & $\begin{array}{l}43.8 \\
40.6\end{array}$ & $\begin{array}{l}.52 \\
.60\end{array}$ & $\begin{array}{r}1.17 \\
.61\end{array}$ \\
\hline 10 & S.A. & $\begin{array}{l}\mathbf{3} \\
\mathbf{3}\end{array}$ & $\begin{array}{l}7.5 \\
3.4\end{array}$ & $\begin{array}{c}1.40 \\
60.3\end{array}$ & 30 & $\begin{array}{r}1.01 \\
.99\end{array}$ & \begin{tabular}{|l|}
50.8 \\
40.4
\end{tabular} & $\begin{array}{r}122.0 \\
42.0\end{array}$ & $\begin{array}{r}115.0 \\
81.1\end{array}$ & $\begin{array}{l}.44 \\
.50\end{array}$ & $\begin{array}{r}1.06 \\
.52\end{array}$ \\
\hline 11 & B.A. & $\begin{array}{l}\mathbf{3} \\
\mathbf{3}\end{array}$ & $\begin{array}{l}6.9 \\
5.1\end{array}$ & $\begin{array}{c}3.25 \\
65.0\end{array}$ & 35 & $\begin{array}{r}.96 \\
1.33\end{array}$ & $\begin{array}{l}48.3 \\
37.4\end{array}$ & $\begin{array}{l}77.7 \\
39.4\end{array}$ & $\begin{array}{r}103.0 \\
76.5\end{array}$ & $\begin{array}{l}.47 \\
.49\end{array}$ & $\begin{array}{l}.75 \\
.51\end{array}$ \\
\hline 13 & S.B. & $\begin{array}{l}\mathbf{3} \\
\mathbf{3}\end{array}$ & $\begin{array}{r}10.9 \\
5.1\end{array}$ & $\begin{array}{l}1.13 \\
63.8\end{array}$ & 28.5 & $\begin{array}{l}1.38 \\
1.55\end{array}$ & \begin{tabular}{|l|}
62.0 \\
54.2
\end{tabular} & $\begin{array}{r}184.0 \\
56.7\end{array}$ & $\begin{array}{r}125.0 \\
96.5\end{array}$ & $\begin{array}{l}.50 \\
.56\end{array}$ & $\begin{array}{r}1.47 \\
.59\end{array}$ \\
\hline
\end{tabular}

filtrates of plasma according to Shannon, Jolliffe and Smith (16).

Ammonia determinations in Experiments 1 to 7 were performed by the permutit-Nesslerization method of Folin and Bell (4) and in Experiments 8 to 12 , by the aeration-titration technique of Van Slyke and Cullen (20).

On the basis of the observations of Shannon (14), the creatinine clearance was used as a measure of the rate of glomerular filtration. Simultaneous creatinine and urea clearances were compared to eliminate errors arising from variations in glomerular activity and in order that the urea/ creatinine clearance ratio would be available to indicate any change in the excretory mechanism of urea, independent of a change in glomerular activity.

Data on a typical experiment in which urea was administered intravenously during extreme acidosis are given in Table I. When the blood urea is low and ammonia furnishes a large fraction of the nitrogen in the urine, both the urea clearance and the urea/creatinine clearance ratio are within the usual range previously observed in dogs on a low protein diet. The urea + ammonia clearance, on 
the other hand, is three times the urea clearance, and considerably above the creatinine or glomerular clearance, an unprecedented situation, for never heretofore has the urea clearance been observed to rise to the level of, much less exceed, the creatinine clearance in any mammal. When the plasma urea is high, and urea predominates over ammonia in the urine, the urea + ammonia clearance approximates the urea clearance observed at the low urea levels, since under these conditions no great elevation in clearance is introduced by the inclusion of ammonia in the calculation. The necessity for a standard of reference (creatinine clearance) for glomerular activity is evident in this experiment, since both the urea and the creatinine clearances fell in consequence of the intravenous injection.

The results obtained in eight experiments of the above type on five dogs are summarized in Table II. In each case three values obtained at low plasma urea levels and three values obtained at high plasma urea levels are averaged. These experiments are concordant in leading to the conclusions reached above, namely, that the inclusion of ammonia in the clearance calculation leads to an erroneously high result, the discrepancy depending on the degree of acidosis and the height of the blood urea. On the other hand, the true urea clearance is essentially the same, relative to creatinine, at all plasma levels of urea. It is evident that the excretion of urea and ammonia are in no wise reciprocally related, and if ammonia is derived from urea it must come at least in part from a source other than urea filtered at the glomerulus.

A second type of experiment was performed in which, after a series of control periods in acidosis, sodium bicarbonate was administered to render the urine alkaline. It was not possible to obtain an immediate reduction of ammonia excretion in all cases, three hours or more being required to effect this in some instances, even after large doses of alkali intravenously and by mouth. A typical experiment for the determination of the effect of sodium bicarbonate is given in Table III. The administration of alkali, by reducing the excretion of ammonia, reduced the urea + ammonia clearance markedly, relative to the creatinine clearance (the reduction was still in prog-
TABLE III

A comparison of the urea, the urea plus ammonia, and the creatinine clearances in the dog under conditions of acidosis and alkalosis

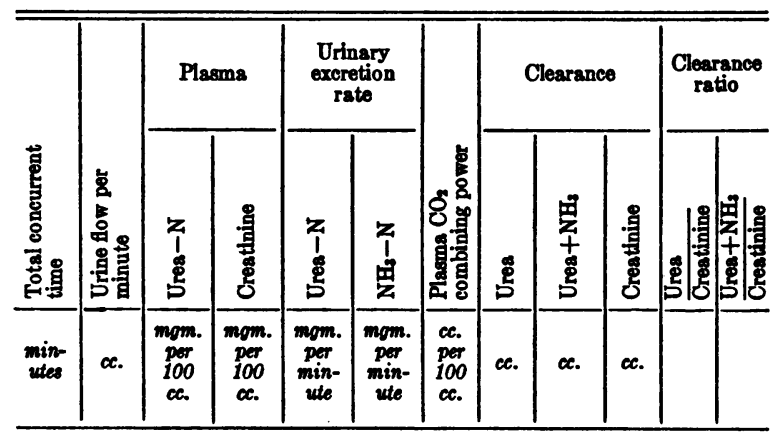

Experiment 12, Dog S.A.

\begin{tabular}{|c|c|c|c|c|c|c|c|c|c|c|c|}
\hline $\begin{array}{l}15 \\
30 \\
45 \\
50\end{array}$ & $\begin{array}{r}9.47 \\
7.87 \\
4.80 \\
\text { S }\end{array}$ & $\begin{array}{l}1.40 \\
1.40 \\
1.40 \\
\text { dium } \mathrm{V}\end{array}$ & $\begin{array}{l}18.8 \\
17.5 \\
16.5\end{array}$ & $\begin{array}{r}.72 \\
.69 \\
.58 \\
\text { to } \mathrm{adm}\end{array}$ & $\begin{array}{c}1.16 \\
1.09 \\
.96\end{array}$ & 33 & $\begin{array}{l}51.4 \\
49.5 \\
41.5\end{array}$ & $\begin{array}{l}135 \\
128 \\
110\end{array}$ & $\begin{array}{r}108 \\
111 \\
96\end{array}$ & $\begin{array}{l}.48 \\
.45 \\
.43\end{array}$ & $\begin{array}{l}1.25 \\
1.15 \\
1.15\end{array}$ \\
\hline $\begin{array}{l}315 \\
330 \\
345\end{array}$ & $\begin{array}{l}7.47 \\
6.00 \\
4.73\end{array}$ & $\begin{array}{l}1.60 \\
1.60 \\
1.60\end{array}$ & $\begin{array}{l}14.5 \\
15.2 \\
15.4\end{array}$ & $\begin{array}{r}1.09 \\
.99 \\
.97\end{array}$ & $\begin{array}{l}.52 \\
.25 \\
.11\end{array}$ & 89 & $\begin{array}{l}68.2 \\
61.9 \\
60.6\end{array}$ & $\begin{array}{c}101 \\
77.2 \\
67.4\end{array}$ & $\begin{array}{l}122 \\
113 \\
113\end{array}$ & $\begin{array}{l}.56 \\
.55 \\
.54\end{array}$ & $\begin{array}{l}.83 \\
.68 \\
.60\end{array}$ \\
\hline
\end{tabular}

ress at the conclusion of the experiment), whereas the urea/creatinine clearance ratio was affected to only a small degree.

Table IV is a summary of 4 such experiments on 4 dogs. It is evident from these experiments that the urea/creatinine clearance ratio is essentially the same in acidosis as in alkalosis. These experiments may also be taken, therefore, to indicate that the inclusion of ammonia in the urea + ammonia clearance of acidosis introduces an error, the magnitude of which is determined by

\section{TABLE IV}

A summary of comparisons of the urea, the urea plus ammonia, and the creatinine clearances in the dog under conditions of acidosis and alkalosis

\begin{tabular}{|c|c|c|c|c|c|c|c|c|c|c|c|}
\hline \multirow{2}{*}{ 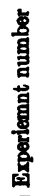 } & \multirow[b]{2}{*}{ 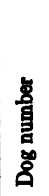 } & \multirow{2}{*}{ 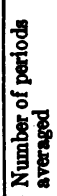 } & \multirow{2}{*}{ 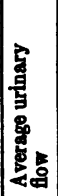 } & \multirow{2}{*}{ 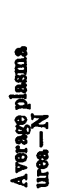 } & \multirow{2}{*}{ 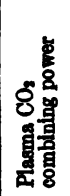 } & \multirow{2}{*}{ 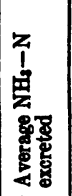 } & \multicolumn{3}{|c|}{ Clearance } & \multicolumn{2}{|c|}{$\begin{array}{c}\text { Clearance } \\
\text { ratios }\end{array}$} \\
\hline & & & & & & & 总 & $\begin{array}{l}\text { 蜜 } \\
\text { 惫 } \\
\text { 员 }\end{array}$ & $\begin{array}{l}\text { 圎 } \\
\text { 总 }\end{array}$ & 䙷 & 畳兽 \\
\hline & & & ce. & $\begin{array}{l}\text { mom. } \\
\text { per } \\
100 \mathrm{cc} .\end{array}$ & $\begin{array}{c}c e . \\
p e r \\
100 \mathrm{ce} .\end{array}$ & $\begin{array}{c}\text { mom. } \\
\text { per } \\
\text { minute }\end{array}$ & $\infty$. & . & $\infty$ & & \\
\hline 3 & 2 & $\begin{array}{l}\mathbf{3} \\
\mathbf{3}\end{array}$ & $\begin{array}{l}2.8 \\
6.6\end{array}$ & $\begin{array}{l}2.16 \\
2.61\end{array}$ & $\begin{array}{l}37.5 \\
75\end{array}$ & $\begin{array}{l}.77 \\
.06\end{array}$ & \begin{tabular}{|l|}
50.5 \\
58.4
\end{tabular} & $\begin{array}{l}86.2 \\
61.0\end{array}$ & $\begin{array}{r}95.8 \\
105.3\end{array}$ & $\begin{array}{l}.53 \\
.55\end{array}$ & $\begin{array}{l}.90 \\
.58\end{array}$ \\
\hline 6 & 4 & $\begin{array}{l}3 \\
3\end{array}$ & $\begin{array}{l}5.5 \\
5.3\end{array}$ & $\begin{array}{l}1.58 \\
1.40\end{array}$ & $\begin{array}{l}31 \\
85\end{array}$ & $\begin{array}{r}1.03 \\
.50\end{array}$ & \begin{tabular}{|l}
39.3 \\
49.2
\end{tabular} & $\begin{array}{r}104.3 \\
85.0\end{array}$ & $\begin{array}{l}79.2 \\
82.1\end{array}$ & $\begin{array}{l}.50 \\
.60\end{array}$ & \begin{tabular}{|l|}
1.31 \\
1.04
\end{tabular} \\
\hline 12 & B.A. & $\begin{array}{l}\mathbf{3} \\
\mathbf{3}\end{array}$ & $\begin{array}{l}7.4 \\
6.1\end{array}$ & $\begin{array}{l}1.40 \\
1.60\end{array}$ & $\begin{array}{l}33 \\
89\end{array}$ & $\begin{array}{r}1.07 \\
.29\end{array}$ & $\begin{array}{l}47.5 \\
63.6\end{array}$ & $\begin{array}{r}123.9 \\
81.8\end{array}$ & $\begin{array}{l}104.9 \\
119.2\end{array}$ & $\begin{array}{l}.45 \\
.53\end{array}$ & $\begin{array}{r}1.18 \\
.69\end{array}$ \\
\hline 14 & S.B. & $\begin{array}{l}\mathbf{3} \\
\mathbf{3}\end{array}$ & $\begin{array}{r}10.3 \\
4.6\end{array}$ & $\begin{array}{r}.62 \\
1.77\end{array}$ & $\begin{array}{l}30 \\
92\end{array}$ & $\begin{array}{r}1.33 \\
.19\end{array}$ & $\begin{array}{l}52.5 \\
63.9\end{array}$ & $\begin{array}{r}267.0 \\
75.0\end{array}$ & $\begin{array}{l}119.0 \\
105.8\end{array}$ & $\begin{array}{l}.44 \\
.60\end{array}$ & $\begin{array}{r}2.24 \\
.71\end{array}$ \\
\hline
\end{tabular}


the relative fraction of ammonia in the urine. From both groups of experiments (Table II and IV) we would conclude that the significance of the urea clearance in acidosis, alkalosis, and in the normal animal is the same.

The question may be raised whether observations on dogs are pertinent to man. The work of Steenbock et al. (18) on calves, of Keeton (6), and of Nash and Benedict (11) on dogs, has been applied to man as the basis of the paper of Van Slyke, Page, Hiller and Kirk (21). We entirely concur in this procedure; it appears at the present time that the urea clearance in man and dog has the same physiological significance, and is similarly related to the rate of glomerular filtration, showing a deficit below the latter in both species for reasons as yet unexplained. The excretion of ammonia in both species has likewise the same general physiological significance, so far as our present information goes. It therefore appears justified to continue to apply results obtained on dogs to man until carefully controlled experiments indicate otherwise.

One of the reasons why Van Slyke et al. (21) recommend the inclusion of ammonia in the determination of the urea clearance in man is the technical ease of the hypobromite method, which includes both forms of nitrogen. Inasmuch as these investigators and others have shown that in the normal and in the nephritic, urinary ammonia nitrogen is never more than a small fraction of the total nitrogen, this method of analysis would not introduce a significant error. But in diabetic acidosis or other conditions where a significant proportion of the urinary nitrogen might be in the form of ammonia, the clearances so obtained would be excessively high, and might even exceed the rate of glomerular filtration as indicated by the inulin clearance (17), even as the urea + ammonia clearances observed here in the dog exceed the creatinine clearance.

Our present experiments throw no light on the nature of the precursor from which urinary ammonia is formed. If urea is that precursor, it is evident that it is not the urea that has passed into the glomerular filtrate. It is, of course, possible that urea might be removed directly from the post-glomerular blood and transformed and deposited as ammonia in the tubular urine by the activity of the tubule cells. But it is just as harmonious with the above presented experimental facts to suppose that urinary ammonia may be formed from amide nitrogen, as suggested by Bliss (2) or from amino nitrogen, as suggested by Krebs (7), or from some other precursor, through the agency of tubule cells.

\section{CONCLUSIONS}

The urea clearance in the dog relative to the creatinine (glomerular) clearance is essentially the same in acidosis and alkalosis as in the normal.

At low plasma urea values in acidosis the urea + ammonia clearance is considerably higher than the urea clearance and may exceed the creatinine (glomerular) clearance. The magnitude of this discrepancy between the urea and the urea + ammonia clearances depends on the degree of acidosis and the height of the plasma urea, being greater the more marked the acidosis and the lower the plasma urea.

The urea + ammonia clearance in acidosis does not have the same significance nor is it of the same magnitude as the urea clearance in the normal animal.

\section{BIBLIOGRAPHY}

1. Adolph, E. F., The metabolism of ammonium salts and of urea in man. Am. J. Physiol., 1924-5, 71, 355.

2. Bliss, S., The amide nitrogen of blood. III. Muscular exercise: The rôle of ammonia in the neutralization of lactic acid. J. Biol. Chem., 1929, 81, 137.

3. Cope, C. L., Studies of urea excretion. VIII. The effects on the urea clearance of changes in protein and salt contents of the diet. J. Clin. Invest., 1933, 12, 567.

4. Folin, O., and Bell, R. D., Applications of a new reagent for the separation of ammonia. I. The colorimetric determination of ammonia in urine. J. Biol. Chem., 1917, 29, 329.

5. Goldring, W., Razinsky, L., Greenblatt, M., and Cohen, S., The influence of protein intake on the urea clearance in normal man. J. Clin. Invest., 1934, 13, 743.

6. Keeton, R. W., Ammonia excretion following experimental administration of acids via the stomach and peripheral vein. J. Biol. Chem., 1921, 49, 411.

7. Krebs, H. A., Untersuchungen über den Stoff wechsel der Aminosäuren im Tierkörper. Ztschr., f. physiol. Chem., 1933, 217, 191.

Weitere Untersuchungen über den Abbau der Aminosäuren im Tierkörper. Ztschr. f. physiol. Chem., 1933, 218, 157. 
8. Loeb, R. F., Atchley, D. W., and Benedict, E. M., Observations on the origin of urinary ammonia. J. Biol. Chem., 1924, 60, 491.

9. Mann, F. C., and Bollman, J. L., The formation of ammonia following complete removal of the liver. Am. J. Physiol. (Proc.), 1928, 85, 390.

10. McCollum, E. V., and Hoagland, D. R., Studies of the endogenous metabolism of the pig as modified by various factors. I. The effects of acid and basic salts and of free mineral acids on the endogenous nitrogen metabolism. J. Biol. Chem., 1914, 16, 299.

11. Nash, T. P., Jr., and Benedict, S. R., The ammonia content of the blood and its bearing on the mechanism of acid neutralization in the animal organism. J. Biol. Chem., 1921, 48, 463.

12. Pitts, R. F., The effect of protein and amino acid metabolism on the urea and xylose clearance. J. Nutrition, 1935, 9, 657.

13. Rabinowitch, I. M., Studies concerning the origin of urinary ammonia. III. J. Biol. Chem., 1926, 69, 283.

14. Shannon, J. A., The excretion of inulin by the dog. Am. J. Physiol., 1935, 112, 405.

15. Shannon, J. A., Jolliffe, N., and Smith, H. W., The excretion of urine in the dog. VI. The filtration and secretion of exogenous creatinine. Am. J. Physiol., 1932, 102, 534.
16. Shannon, J. A., Jolliffe, N., and Smith, H. W., The excretion of urine in the dog. IV. The effect of maintenance diet, feeding, etc. upon the quantity of glomerular filtrate. Am. J. Physiol., 1932, 101, 625.

17. Shannon, J. A., and Smith, H. W., The excretion of inulin, xylose and urea by normal and phlorizinized man. J. Clin. Invest., 1935, 14, 393.

18. Steenbock, H., Nelson, V. E., and Hart, E. B., Acidosis in omnivora and herbivora and its relation to protein storage. J. Biol. Chem., 1914, 19, 399.

19. Van Slyke, D. D., Determination of urea by gasometric measurement of the carbon dioxide formed by the action of urease. J. Biol. Chem., 1927, 73, 695.

20. Van Slyke, D. D., and Cullen, G. E., A permanent preparation of urease and its use in the determination of urea. J. Biol. Chem., 1914, 19, 211.

The determination of urea by the urease method, Ibid., 1916, 24, 117.

21. Van Slyke, D. D., Page, I. H., Hiller, A., and Kirk, E., Studies of urea excretion. IX. Comparison of urea clearances calculated from the excretion of urea, of urea plus ammonia, and of nitrogen determinable by hypobromite. J. Clin. Invest., 1935, 14, 901. 